\title{
THE EURO AND THE VOLATILITY OF EXCHANGE RATES
}

\author{
January 2011 \\ Amalia Morales-Zumaquero \\ Departamento de Teoría e Historia Económica, Facultad de Ciencias Económicas y \\ Empresariales, Universidad de Málaga, Campus de El Ejido 29071 Málaga, Spain, \\ amalia@uma.es \\ Corresponding author: Simón Sosvilla-Rivero \\ Departmento de Economía Cuantitativa, Facultad de Ciencias Económicas y \\ Empresariales, Universidad Complutense de Madrid, Campus de Somosaguas, 28223 \\ Madrid, Spain, sosvilla@ccee.ucm.es
}

\begin{abstract}
This paper attempts to determine whether or not the introduction of the euro affected the volatility of major bilateral exchange rates. To that end, we examine the exchange rate behaviour for a set of OECD and non-OECD countries during the 19932010 period. We find evidence of structural breaks in volatility across investigated variables and, although there is a high heterogeneity regarding the located dates, our results suggest a reduction in volatility associated with EMU and worldwide shocks and an increase in volatility following shocks originating outside EMU. The decomposition of total volatility into its components suggest that the permanent component tracks total volatility reflecting the evolution of fundamental factors and the transitory component responds largely to market fluctuations, rising during the detected structural breaks.
\end{abstract}




\section{Introduction}

The launch of the euro on 1 January 1999, and the introduction of euro notes and coins on 1 January 2002, meant that the European Union (EU) achieved a long-standing ambition to cement closer economic integration with a single currency.

European Economic and Monetary Union (EMU) is a monetary integration scheme without precedent in terms of its scale and complexity, and it is unique in that it combines centralised conduct of monetary policy by the European Central Bank (ECB) with national sovereignty over fiscal and other economic policies (albeit within a common framework). EMU also represents the most important change in the global economic system since the collapse of the Bretton Woods system of fixed exchange rates in the early 1970s (see, e. g., Mundell, 2000). It was expected that EMU would help to deliver macroeconomic stability through a sound single monetary policy and much improved fiscal behaviour in member countries, as well as acting as a powerful catalyst for financial market integration.

Prior to 1999, speculation abounded about how much of an international role the single currency would play. Since then, the euro has become a leading financial currency, making substantial gains in some international currency functions. The euro's share of international debt securities is greater than that of the US dollar, with the single currency accounting for nearly half of the world stock. In addition, the euro has become the second most used reserve currency, rising from $18 \%$ in 1999 to over $27 \%$ in 2009 (IMF, 2010), and the second most actively traded currency in foreign exchange markets worldwide, accounting for 39 per cent of all transactions in 2010 (BIS, 2010). As the 
international status of the single currency has clearly conferred certain benefits on euroarea members, there is not available evidence whether the euro, at a time of dollar volatility, has provided a much-needed anchor for the global economy.

Most of the existing literature concluded that the exchange rate volatility of the euro would increase as a result of EMU [see, among others, Krugman (1989), Alosgoufis and Portes (1997), McCauley (1997), Demertzis and Hughes Hallet (1998), Coeuré and Pisani-Ferry (2000) and Frieden (2000)]. These papers stressed either the possibility of the ECB giving priority to internal price stability over the external value of the euro (leading to higher exchange rate volatility than before) or the fact that the external adjustment channel would become narrower and a larger exchange rate adjustment would be required to restore internal price stability after a shock. In contrast, Martin (1998), using a simple two-country model with random supply shocks, concluded that exchange rate volatility was likely to decline after EMU when compared to a situation of floating rates.

This paper tries to shed some light on this issue by offering empirical evidence on whether or not the introduction of the euro affected the volatility of bilateral exchange rates all over the world ${ }^{1}$. To that end, we examine the exchange rate behaviour for a set of OECD and non-OECD countries during the 1993-2010 period. Firstly, we implement two econometric methods for testing for structural breaks: the OLS-based tests to detect multiple structural breaks, as proposed by Bai and Perron (1998, 2003), and several procedures based on Information Criterion together with the so-called sequential procedure suggested by Bai and Perron (2003). Secondly, we explore the

\footnotetext{
${ }^{1}$ The impact of exchange rate volatility on international trade has been widely tested. Some recent examples are, Solakoglu, Solakoglu and Demirağ (2008), Aliyu (2010), Boug and Fagereng (2010) and Solakoglu (2010) among others.
} 
permanent and transitory nature of exchange-rate volatility using Engel and Lee (1999)'s component-GARCH model.

The paper is organised as follows. Section 2 provides the theoretical framework underlying the study. Section 3 describes the econometric methodology adopted in this study. Section 4 presents the data and the empirical result, and Section 5 offers some concluding remarks.

\section{Theoretical framework}

Martin (1998) develops a two country model in which unanticipated changes in the exchange rate can help countries stabilize their economy when shocks occur. He finds that the relation between size and exchange rate variability is not a simple linear one and, given that EMU entails the creation of a very large common currency zone, he predicts that the euro exchange rate should be more stable than the previous European currencies.

Cavelaars (2002) extends Martin (1998)'s model to a three-country version in order to address the internalisation of externalities between two countries in the presence of a third country, where strategic interaction among all central banks is explicitly modelled, following the Canzoneri and Henderson (1991) approach. This model allows to look explicitly at the impact of asymmetric shocks in the euro area on exchange rate stability, finding that the impact of EMU on exchange rate stability critically depends on the origin of shocks. On the one hand, under EMU, the exchange rate will react more moderately to European supply shocks than before. The more 
moderate response of the ECB implies that the policy responses of the ECB and the Fed to a euro area supply shock will be more alike than before, which results in a more stable exchange rate. On the other hand, the impact of US shocks on the exchange rate will become stronger under EMU. The more moderate response of the ECB to a US shock implies that the policy stance of the ECB and the Fed will diverge more than before. This causes the dollar to respond more strongly to a supply shock in the US. This seems to confirm the findings according to which the creation of EMU mitigates the reaction of central bank to economic shocks, as a result of policy co-ordination.

The conclusions remain valid when taking into account that Europe had an exchange rate mechanism (ERM), rather than freely floating currencies, in the pre-EMU era. The specification of the ERM accounts for the fact that the ERM was an asymmetric arrangement, in the sense that the Bundesbank had a leading role, whereas the other national central banks had an exchange rate target against the German Mark (see Bajo-Rubio et al., 2001).

Finally, the model's country size parameter is used to test what happens if the euro area expands. This is likely to become relevant, given the foreseen enlargement of the EU and the expected future participation of the new member states in the monetary union. Most of the results do not change. However, if the euro area were to become significantly larger than the US, the exchange rate may become more, not less, responsive to a symmetric worldwide shock than it used to be before EMU. 


\section{Econometric Methodology}

\subsection{Testing for Structural Breaks}

Recent econometric methodology for detecting structural breaks is based on testing endogenously the presence of structural breaks of an unknown location. In this sense, three main approaches have been developed: the CUSUM-type tests, such as the iterated cumulative sums of squares (ICSS) algorithm by Inclán and Tiao (1994), to test for structural breaks in variance; the OLS-based tests to detect structural breaks in mean or/and variance (Quandt, 1960; Andrews, 1993; Andrews and Ploberger, 1994; Hansen, 1997; Bai and Perron, 1998, 2003); and, finally, the procedures based on Information Criterion (Liu et al., 1997; Bai and Perron, 1998, 2003). This paper uses the two last approaches. We concentrate on the last two approaches given that the ICSS algorithm presents several weaknesses such as this test is based on the assumption that the disturbances are independent and Gaussian distributed. This assumption could be considered as extreme for financial time series that usually exhibit empirical distributions with fat fails and persistence in conditional variance. So, the test suffers important size distortions for leptokurtic and platykurtic innovations, being these size distortions more extreme when the volatility follows a GARCH process (for a further discussion see, for example, Sansó, Aragó and Carrión, 2004 and Valentinyi-Endrész, 2004). 
Bai and Perron $(1998,2003)^{2}$ consider the following multiple linear regression with $m$ breaks ( $m+1$ regimes):

$$
\begin{gathered}
y_{t}=x_{t}^{\prime} \beta+z_{t}^{\prime} \delta_{1}+u_{t}, \quad t=1, \ldots, T_{1}, \\
y_{t}=x_{t}^{\prime} \beta+z_{t}^{\prime} \delta_{2}+u_{t}, \quad t=T_{1}+1, \ldots, T_{2}, \\
\vdots \\
y_{t}=x_{t}^{\prime} \beta+z_{t}^{\prime} \delta_{m+1}+u_{t}, \quad t=T_{m}+1, \ldots, T .
\end{gathered}
$$

In this model, $y_{t}$ is the observed dependent variable at time $t ; x_{t} \quad(p \times 1)$ and $z_{t}$ $(q \times 1)$ are vectors of covariates and $\beta$ and $\delta_{\mathrm{j}} \quad(j=1, \ldots, m+1)$ are the vectors of coefficients, respectively. Finally, $u_{t}$ is the disturbance at time $t$. The break points $\left(T_{1}, \ldots, T_{m}\right)$ are unknown. The purpose is to estimate the unknown regression coefficients and the break points using a sample of $T$ observations.

We consider a pure structural change model $(p=0)$, where all the coefficients are subject to change, from the model in equation (1). In this sense, we specify each series as an $\mathrm{AR}(1)$ process and then, to detect multiple structural breaks in variance, we use the absolute value of the fitted residuals of the AR(1) models ${ }^{3}$. For this analysis we specify $z_{t}=\{1\}$.

To detect multiple structural breaks, we use the following set of tests developed by Bai and Perron $(1998,2003)^{4}$ : the sup $F$ type test, the double maximum tests and the test for $\ell$ versus $\ell+1$ breaks. In first place, we consider the $\sup F$ type test of no

\footnotetext{
${ }^{2}$ We are particularly grateful to Bai and Perron for providing us with the GAUSS code for computations. ${ }^{3}$ Similarly, Stock and Watson (2002) use the absolute value of the fitted residuals of a VAR model to analyse changes in variance. Alternatively, Valentinyi-Endrész (2004) use the squared errors from a AR(1)-GARCH $(1,1)$ model to compute changes in variance.

${ }^{4}$ For further analysis see Bai and Perron $(1998,2003)$.
} 
structural breaks $(m=0)$ versus the alternative hypothesis that there are $m=k$ breaks. In second place, we employ the double maximum tests, UDmax and WDmax. They contrast the null hypothesis of no structural breaks against an unknown number of breaks given some upper bound M. Finally, we use the test for $\ell$ versus $\ell+1$ breaks, the labelled $\sup F_{T}(\ell+1 / \ell)$ test. The method involves the application of the $(\ell+1)$ test of the null hypothesis of no structural change versus the alternative hypothesis of a single change. The test is applied to each segment containing the observations $\hat{T}_{i-1}$ to $\hat{T}_{i}$ $i=1, \ldots,(\ell+1)$.

To run these tests it is necessary to decide the minimum distance between two consecutive breaks, $h$, that it, is obtain as the integer part of a trimming parameter, $\varepsilon$, multiplied by the number of observations $T$ (we use $\varepsilon=0.15$ and allow up to 5 breaks for the full sample analysis, and $\varepsilon=0.20$ and up to 3 breaks for the sub-period analysis).

To select the dimension of the models, following the suggestions by Bai and Perron (2003), we consider the Bayesian Information Criterion (BIC) developed by Yao (1988), and a modified Schwarz' criterion -the LWZ criterion- proposed by Liu, Wu and Zidek (1994). In addition, we follow the method suggested by Bai and Perron (1998) based on the sequential application of the $\sup F_{T}(\ell+1 / \ell)$ test, the sequential procedure (SP). This method begins by estimating a model with a small number of breaks thought to be necessary. Parameter-constancy tests are then performed for each sub-period, adding a break to a sub-period associated with a rejection with the test sup $F_{T}(\ell+1 / \ell)$. This process is repeated by increasing $\ell$ sequentially until the test sup $F_{T}(\ell+1 / \ell)$ fails to reject the null hypothesis of no additional structural breaks. 


\subsection{Testing for Permanent and Transitory Components}

Engle and Lee (1999) proposed a "component-GARCH" (C-GARCH) model to decompose time-varying volatility into a permanent (long-run) and a transitory (shortrun) component.

Consider the original GARCH model:

$$
\sigma_{t}^{2}=\omega+\alpha\left(\varepsilon_{t-1}-\omega\right)+\beta\left(\sigma_{t-1}^{2}-\omega\right)
$$

As can be seen, the conditional variance of the returns here has mean reversion to some time-invariable value, $\omega$. The influence of a past shock eventually decays to zero as the volatility converges to this value according to the powers of $(\alpha+\beta)$. The standard GARCH model therefore makes no distinction between the long-run and short-run decay behavior of volatility persistence.

For the permanent specification, the $\mathrm{C}-\mathrm{GARCH}$ model replaces the timeinvariable mean reversion value, $\omega$, of the original GARCH formulation in equation (6) with a time variable component $q_{t}$ :

$$
q_{t}=\hat{\omega}+\rho\left(q_{t-1}-\hat{\omega}\right)+\varphi\left(\varepsilon_{t-1}^{2}-\sigma_{t-1}^{2}\right)
$$

Here, $q_{t}$ is the long-run time-variable volatility level, which converges to the long-run time-invariable volatility level $\hat{\omega}$ according to the magnitude of $\rho$. This permanent component thus describes the long-run persistence behaviour of the variance. The longrun time-invariable volatility level $\hat{\omega}$ can be viewed as the long-run level of returns variance for the relevant sector when past errors no longer influence future variance in any way. Stated differently, the value $\hat{\omega}$ can be seen as a measure of the 'underlying' level of variance for the respective series. The closer the estimated value of the $\rho$ in 
equation (7) is to one the slower $q_{t}$ approaches $\hat{\omega}$, and the closer it is to zero the faster it approaches $\hat{\omega}$. The value $\rho$ therefore provides a measure of the long-run persistence.

The second part of $\mathrm{C}-\mathrm{GARCH}$ model is the specification for the short-run dynamics, the behaviour of the volatility persistence around this long-run time-variable mean, $q_{t}$ :

$$
\sigma_{t}^{2}-q_{t}=\gamma\left(\varepsilon_{t-1}^{2}-q_{t-1}\right)+\lambda\left(\sigma_{t-1}^{2}-q_{t-1}\right)
$$

According to this transitory specification, the deviation of the current condition variance from the long-run variance mean at time $t\left(\sigma_{t}^{2}-q_{t}\right)$ is affected by the deviation of the previous error from the long-term mean $\left(\varepsilon_{t-1}^{2}-q_{t-1}\right)$ and the previous deviation of the condition variance from the long-term mean $\left(\sigma_{t-1}^{2}-q_{t-1}\right)$. Therefore, in keeping with its GARCH theoretical background, the C-GARCH specification continues to take account of the persistence of volatility clustering by having the conditional variance as a function of past errors. As the transitory component describes the relationship between the short-run and long-run influence decline rates of past shocks values of $(\gamma+\lambda)$ closer to one imply slower convergence of the short-run and long-run influence decline rates, and values closer to zero the opposite. The value $(\gamma+\lambda)$ is therefore a measure of how long this non-long-run (i.e. short-run) influence decline rate is.

Together, these two components of the C-GARCH model describe, just like the original GARCH formulation, how the influence of a past shock on future volatility declines over time. With the C-GARCH model however, this persistence is separated into a short-run and long-run component, along with the estimation of the underlying variance level once the effect of both components has been removed from a series. The 
transitory component represents short-run volatility conditioned by financial market considerations, such as the arrival of new information, speculation and hedging positions. On the other hand, the permanent component of volatility characterizes periods of change in the exchange rate that stem from macroeconomic adjustments in economic fundamentals [see, for example, Blake and McMillan (2004) and Byrne and Davis (2005)].

\section{Data and Empirical Results}

\subsection{Data}

We use daily data of nominal exchange rates against the Euro from 4/01/1993 to 22/09/2010 $0^{5}$ taking from Reuters' EcoWin Pro for a sample of 32 countries: Austria, Australia, Belgium, Bulgaria, Canada, Switzerland, Cyprus, Denmark, Czech Republic, Spain, Finland, France, United Kingdom, Hong Kong, Hungary, Ireland, Iceland, Italy, Japan, Korea, Luxemburg, Malta, New Zealand, Portugal, Romania, Russia, Swiss, Slovenia, Slovakia, Turkey, United States and South Africa.

In our empirical analysis, we have considered the following sub-samples of countries:

i. Group of Seven, G-7: Canada, Germany, France, United Kingdom, Italy, Japan and United States of America.

ii. European countries: Austria, Belgium, Switzerland, Cyprus, Denmark, Spain, Ireland, Luxembourg, Malta, Norway, Portugal, Sweden and Turkey.

\footnotetext{
${ }^{5}$ This period differs between series depending on data availability.
} 
iii. Transition economies: Bulgaria, Czech Republic, Hungary, Poland, Romania, Russia, Slovenia and Slovakia.

iv. Other countries: Australia, Hong Kong, Iceland, Korea, New Zealand and South Africa.

Figures 1(a) to 1 (d) plot the first log differences of the daily exchange rate of the euro against the currencies of each group of countries we have considered in our empirical analysis. A simple look at these figures show the differences in the exchange rate volatility before and after 1999 or 2002 for most of the currencies, as well as during the recent turmoil in 2008 .

[Insert Figures 1(a) to 1(d) here]

\subsection{Empirical Results for Structural Breaks}

The results for the structural breaks are displayed in Tables 1 to 4, offering four sets of information. In the first place, we present in Columns 2 to 6 the numerical results of the statistics we have described in Section 2. In the second place, we show in Column 7 the number of breaks selecting by the SP. In the third place, we present in Columns 8 to 12 the estimated final model and, finally, in the last columns, the dates of the breaks are reported and the increase or reduction in volatility suggested by the coefficient estimates after the break.

Let us now discuss the results obtained for the different groups of countries examined in this paper. Regarding the bilateral nominal exchange rate with the 
currencies of the group of most industrialized nations (Table 1), results show, on one hand, that there are four out of the seven currencies with three structural breaks in variance, two out of seven currencies with four breaks in variance, and, finally, one currency out of seven with five breaks in variance. Therefore, our results suggest the existence of at least three breaks in the volatility in the exchange rate of the euro against the G-7 currencies. The break point, as identified, varies from currency to currency in general. Recall that these breaks are searched endogenously from the data and our procedure does not rely on pre-test information to determine them, thereby avoiding the possible problem of "data mining".

In particular, the breaks detected in November and December 1993 in the Deutchemark and the French Frank could be related to the completion of the single market that marked the start of stage one of EMU, while the break identified in 1996 for the Italian Lira coincides with the its re-entry in the Exchange Rate Mechanism (ERM) of the European Monetary System after four years of floating. Furthermore, other breaks are associated to episodes starting with global turmoil, such as the spillover during 1995 from the Mexican financial crisis, the East Asian financial crisis in July 1997, the collapse of Long Term Capital Management and the Russian bond default in August and September 1998 or the terrorist attacks in September 2001. Regarding the 2003 break detected in the US Dollar, it coincides with the substantial uncertainty surrounding the onset of war in Iraq. The 2007 break in Japan could be related to the serious downturn driven largely by declines in investment and weaker consumption growth. As for the 2008 break detected in Canada, UK and USA it could be associated with the collapse of US investment bank Lehman Brothers, after the effective nationalisation of the US federal mortgage agencies. 
[Table 1, here]

Regarding the volatility of the exchange rate of the euro vis-à-vis the currencies of the European countries, results in Table 2 also suggest the existence of at least two break points. The breaks detected in November and December 1993 in the Austrian schilling and the Portuguese escudo, as well as the break identified in January 1994 in the Spanish peseta could be linked to the start of stage one of EMU, while the breaks found in the first months of 1999 in the Cyprus pound, the Danish krone and the Norwegian krone could be related with the third stage of EMU. There are also breaks in 1998 that could be associated with the formal evaluation of Member States to join the euro. Regarding the Turkish lira, the breaks detected in 2001 and 2003 could be justified by the Turkish Stock Market Crash and the Iraqi war, respectively. The break detected in March 2004 in the Maltese lira could be related with the changes made by the ECB in the operational framework for the implementation of monetary policy. As for the breaks found in 2007, they are related with changes in the Danmarks Nationalbank's and Swiss National Bank's monetary-policy instruments. Concerning the break detected in Norway and Sweden in September 2008, it is associated with the turmoil originated in September spreading the crisis beyond the financial markets. Finally, the 2009 break detected in Turkey could be related with changes in the ECB's monetary-policy instruments.

[Table 2, here]

When examining the volatility of the exchange rate of the euro against the currencies of our sample of transition economies (Table 3), we find the presence of at 
least one break point. The break detected for the Czech koruna, the Hungarian forint, the Polish zloty, the Slovenian tolar and the Slovak koruna roughly coincide with episodes of implicit bands in their exchange rates vis-à-vis the euro detected in Ledesma-Rodríguez et al. (2009), that these authors interpret as an attempt by the National Central Banks to borrow European Central Bank's anti-inflation reputation. Furthermore, for the Slovenian tolar and the Slovak koruna, the volatility decreased after formally joining the ERM-II linking them to the euro. Regarding the Bulgarian lev, the Romanian lei and the Russian ruble, there is evidence of break in volatility around August 1998 associated with the Russian financial crisis. The 2007 break detected in Slovakia is associated with the realignment of the Slovak koruna in the ERM-II in March and the subsequent lowering of the Národná banka Slovenska's policy rate to stabilise the koruna vis-à-vis the euro. The 2008 break in the Czech Republic, Hungary, Poland and Russia could be related with the uncertainty in global financial markets following the collapse of Lehman Brothers in September 2008, the deteriorating economic outlook in Europe, and investors' concerns about external vulnerabilities in the region. Lastly, with regard to the 2009 break found in Romania, the central bank adopted monetary policy measures which often mirrored moves by the ECB, widening banks' net liquidity to smooth functioning of the interbank money market and to avoid fuelling excessive exchange rate volatility.

[Table 3, here]

As for the volatility of the exchange rate of the euro vis-à-vis the currencies of our group of other countries, the results in Table 4 indicate the existence of at least four break points. The break detected in 1997 is associated once again with unprecedented 
currency and financial market turmoil in a number of Asian countries. Regarding the breaks identified in 2000 and 2001, they could be related increased uncertainty regarding the relative growth prospects in the major economic areas, while the breaks in 2002 and 2003 were the consequences of increasing geopolitical tensions. As for the 2007 break found in Iceland, it coincides with a worsening of financial conditions and the depreciation of the króna [which was ranked by The Economist (2007) as the most overvalued currency in the world]. Regarding the 2007 break in Australia, it can be associated with purchases of Australian dollars by the Reserve Bank of Australia after reaching its highs. Lastly, the 2008 breaks detected in Australia, Korea and New Zealand are again associated with the pronounced intensification of the global financial turmoil, while the one found in South Africa could be related with the deterioration in sovereign risk in rand-denominated bond yields.

\section{[Table 4, here]}

Concerning the interpretation of the results in the light of the theoretical model proposed by Cavelaars (2002), in most of the cases it can be argued that the process describing exchange rate volatility would have experienced a reduction associated with EMU and worldwide shocks, whereas it would have registered an increase with shocks that originated outside EMU. The former being consistent with the substantial decline in macroeconomic volatility registered in the last decades of the $20^{\text {th }}$ century, denoted by several authors as "the Great Moderation" (see, e. g. Stock and Watson, 2002).

Finally, regarding the impact on exchange rate stability, in 22 out of the 32 cases examined, the coefficient estimates seem to indicate a reduction in exchange-rate 
volatility, at least before the mortgage loans crisis in the US. Regarding exchange rate developments since the outbreak of the recent financial turbulence, foreign exchange markets have witnessed sharp swings in all major bilateral rates. In 14 currencies we found breaks associated with increased exchange-rate volatility and in only three currencies (Slovak koruna, Turkish lira and Romanian leu) we detected breaks implying lower volatility. This could be reflected the market perception that the turbulence originated in the United States as well as the international status of the dollar, playing the role of safe haven in periods of heightened risk aversion.

\subsection{Empirical Results for Permanent and Transitory Components}

In order to have a visual representation of the role played by the two volatility components of the conditional variance, Figures 2(a) to 2 (d) plot the time evolution of the total variance, permanent variance and transitory variance for the daily exchange rate of the euro against the currencies of each group of countries under study. In general, the plots indicate that the permanent component has smooth movements and approaches a moving average of the GARCH volatility, while the transitory component responds largely to market fluctuations, tracking much of the variation in conditional volatility. Consistent with the findings of Engle and Lee (1999), Alizadeh et al. (2002) and Brandt and Jones (2006), we show that the long-run component is characterised by a time varying but highly persistent trend, while the short run component is strongly mean-reverting to this trend. For all currencies and periods, the temporary component of volatility is much smaller than the permanent component. This suggests that transitory shifts in financial market sentiment tend to be less important determinants of exchange 
rate volatility than shocks to the underlying fundamentals ${ }^{6}$. Yet, relative to its lower mean level, the transitory component is in all cases much more volatile than the longrun trend level of volatility, as one would expect. Finally, it is worth noting that the inflection points of the three volatilities are roughly coincident with the structural breaks we have previously detected, giving further support to our results.

[Insert Figures 2(a) to 2(d) here]

The results for the G-7 currencies (Figure 2a) suggest that in the cases of the Canadian dollar, the US dollar, the British pound, the Japanese yen and the Swiss franc some shocks $\varepsilon_{t-1}^{2}$ conveys information relevant to the long-run level of the variance, causing the trend to fluctuate sharply at some dates, specially after the financial turbulence in the summer of 2007. In contrast, the behaviour of the permanent component of the French franc, the Deutsche mark and the Italian lira indicates a smooth and continuous reduction in long-run volatility that is also detected for the EU currencies (Figure 2b), implying that EMU would favour lower transitory exchange rate volatility and being consistent with other evidence on growing economic and financial integration in the EU [see Black and McMillan (2004) and Fidrmuc and Korhonen (2006), among others] $]^{7}$. In contrast, the reduction in volatility is not found either for the Swedish krona (that does not participate in ERM II, but traded under a flexible exchange rate regime) or for non-UE currencies (the Norwegian krone and the Turkish lira).

\footnotetext{
${ }^{6}$ This finding is in line with Lyons (2001) and Evans and Lyons (2002), who show that private information about the state of economic fundamentals is only gradually aggregated in the market and can generate exchange rate volatility.

${ }^{7}$ It should be noticed that the launch of the ERM fostered economic integration and the co-ordination of economic policies in the EU, later formalized in a clear framework through the Maastricht Treaty.
} 
As for the volatility of the exchange rate of the euro vis-à-vis the currencies of the transition economies and our group of other countries, there are significant swings in the permanent or fundamental component, although there is a general trend towards lower volatility that is interrupted after 2007. For several currencies, the standard deviation of the short-run component exceeds that of the long-run component, reflecting periods of temporary turbulence in these markets: the Asian currency and financial crisis, the Russian debt moratorium, the crash of the dot-com bubble, the two Gulf wars and the subprime mortgage crisis.

\section{Concluding Remarks}

The purpose of our paper has been to contribute to the debate on the possible stabilising effect of the euro on the volatility of the exchange rate worldwide. To that end, we have first examined the instability in terms of multiple structural breaks in the variance in the time series of thirty two currencies compromising the Group of Seven, European countries, Transition Economies and Non-European countries. In particular, we have presented the results of applying two alternative procedures for searching endogenously without using a priori information: the OLS-based tests to detect multiple structural breaks, proposed by Bai and Perron $(1998,2003)$ and several procedures based on Information Criterion joint with the so called sequential procedure suggested by Bai and Perron (2003). We then employ the component GARCH model proposed by Engle and Lee (1999) to decompose volatility into a permanent long-run trend component and a transitory short-run component that is mean-reverting towards the long-run trend. 
The main results are as follows. First, we found some evidence of structural breaks in volatility across investigated exchange rates, suggesting in most of the cases a reduction in exchange-rate volatility, at least before the global financial crisis of 20072010. Secondly, there is high heterogeneity between series regarding the dates in which the break points are located, although major economic events in the underlying economies seem to provide reasonable explanations for them. Thirdly, and in line with the theoretical model proposed by Cavelaars (2002), reductions in volatility are associated with EMU and worldwide shocks (with ERM discipline playing a significant role in the reduction of volatility in some European countries and transition economies), while increases in volatility are registered with shocks originating outside EMU. Fourthly, we detect an increase in volatility in some currencies after the 2007 financial turbulence. Finally, the decomposition of total volatility into its components suggest that the permanent component tracks total volatility reflecting the evolution of fundamental factors and the transitory component responds largely to market fluctuations, rising during the detected structural breaks.

Therefore, our results seems to indicate that EMU not only has led to vanishing exchange rate volatility within the euro area, but this volatility has been transferred to the euro exchange rate against third country currencies as some economists had predicted.

\section{Acknowledgements}

The authors are also grateful for financial support from the Spanish Ministry of Science and Innovation (ECO2008-05565). The views expressed here are those of the authors and not necessarily those of the institutions with which they are affiliated. 


\section{References}

Aliyu, S. U. R. (2010) Exchange rate volatility and export trade in Nigeria: an empirical investigation, Applied Financial Economics, 20, 1071 - 1084

Alizadeh, S., M. Brandt and Diebold, F. (2002) Range-based estimation of stochastic volatility models, Journal of Finance, 57, 1047-92.

Alosgoufis, G. and Portes, R. (1997) The euro, the dollar and the international monetary system, in EMU and the International Monetary System, (Eds) P. R. Masson, T. H. Krueger and B. G. Turtelboom, International Monetary Fund, Washington DC, pp. 5878

Andrews, D. (1993) Test for parameter instability and structural change with Unknown change point, Econometrica, 61, 821-856.

Andrews, D. and Ploberger, W. (1994) Optimal tests when a nuisance parameter is present only under the alternative, Econometrica, 62, 1383-1414.

Bai, J. and Perron, P. (1998) Estimating and testing linear models with multiple structural changes, Econometrica, 66, 47-78.

Bai, J. and Perron, P. (2003) Computation and analysis of multiple structural change models, Journal of Applied Econometrics, 18, 1-22. 
Bajo-Rubio, O., Sosvilla-Rivero, S. and Férnandez-Rodríguez, F. (2001) Asymmetry in the EMS: New evidence based on non-linear forecasts, European Economic Review, $\mathbf{4 5 ,}$ 451-473.

Bénassy-Quéré, A. Mojon, B. and Pisani-Ferry, J. (1997) The euro and exchange rate stability, in EMU and the International Monetary System, (Eds) P. R. Masson, T. H. Krueger and B. G. Turtelboom, International Monetary Fund, Washington DC, pp. 157-193.

BIS (2010): Triennial Central Bank Survey of Foreign Exchange and Derivatives Activity in April 2010: Preliminary Results, Bank for International Settlements, Basilea. Available at http://www.bis.org/publ/rpfx10.pdf

Black, A. J. and McMillan, D. G. (2004) "Long-run trends and volatility spillovers in daily exchange rates, Applied Financial Economics, 14, 895-907.

Blake, A. J. and McMillan, D. G. (2004): Long run trends and volatility spillovers in daily exchange rates, Applied Financial Economics, 14, 895-907.

Boug, P. and Fagereng, A. (2010) Exchange rate volatility and export performance: a cointegrated VAR approach, Applied Economics, 42, 851-864.

Brandt, M and Jones, C. (2006) Volatility forecasting with range-based EGARCH models, Journal of Business and Economic Statistics, 24, 470-486. 
Byrne, J. P. and Davis, E. P. (2005) The impact of short- and long-run exchange rate uncertainty on investment: A panel study of industrial countries, Oxford Bulletin of Economics and Statistics, 67, 307-329.

Cavelaars, P. A. D. (2002) EMU, monetrary policy interactions and exchange rate stability, De Economist, 150, 53-82.

Canzoneri, M. B. and Henderson, D. W. (1991) Macroeconomic Policy in Interdependent Economies: A Game-Theoretic Approach, The MIT Press, Cambridge, Ma.

Coeuré, B. and Pisani-Ferry, J. (2000) The euro, yen and dollar: Making the case against benign neglect, in Reforming the International Monetary and Financial System, (Eds.) P. Kenen and L. Swoboda, International Monetary Fund, Washington DC, pp. $19-46$

Demertzis, M. and Hallett, A. H. (1998) EMU and the external value of the euro, Discussion Paper, No. 2058, Centre for Economic Policy Research, London.

Engle, R. F. and Lee, G. G. J. (1999) A permanent and transitory component model of stock return volatility, in Cointegration, Causality, and Forecasting: A Festschrift in Honor of Clive W.J. Granger, R. Engle and H. White (eds.), Oxford University Press, Oxford, 475-497.

Evans, M. and Lyons, R. (2002) Order flow and exchange rate dynamics, Journal of 
Political Economy, 110, 170-180.

Fidrmuc, J. and Korhonen, I. (2006), Meta-analysis of business cycle correlation between the euro area and the CEECs, Journal of Comparative Economics, 34, 518537.

Frieden, J. A. (2000) The political economy of the euro as an international currency, in The Euro as a Stabilizer in the International Economic System, R. Mundell and A. Clesse (eds.), Kluwer Adademic Publishers, Boston, 203-213.

Hansen, B. E. (1997) Approximate asymptotic p values for structural-change tests, Journal of Business and Economic Statistics, 15, 60-67.

IMF (2010) Currency Composition of Official Foreign Exchange Reserves, December 30, 2010. International Monetary Fund, Washington, D. C. Available at http://www.imf.org/external/np/sta/cofer/eng/cofer.pdf

Inclán, C. and Tiao, G. (1994) Use of cumulative sums of squares for retrospective detection of changes of variance, Journal of the American Statistical Association, 424, 913-923.

Krugman, P. R. (1989) Exchange-rate instability, The Lionel Robbins Lectures Series, MIT Press, Cambridge Ma. 
Liu, J.S., Wu, S., and Zidek, J.V. (1997) On segmented multivariate regressions, Statistica Sinica, 7, 497-525.

Lyons, R. (2001) The Microstructure Approach to Exchange Rates, The MIT Press, Cambridge, Mass.

Martin, P. (1998) The exchange rate policy of the Euro: A matter of size? Journal of the Japanese and International Economies, 12, 455-482.

McCauley, R. N. (1997) The euro and the dollar, Working Paper, No. 50, Bank for International Settlement, Basle.

Mundell, R. (2000) The euro and the stability of the international monetary system, in The Euro as a Stabilizer in the International Economic System, R. Mundell and A. Clesse (eds.), Kluwer Adademic Publishers, Boston, 57-84.

Quandt, R.E. (1960) Tests of the hypothesis that a linear regression system obeys two separate regimes, Journal of American Statistical Association, 55, 324-330.

Ledesma-Rodríguez, F., Pérez-Rodríguez, J. and Sosvilla-Rivero, S. (2009) Implicit exchange regimes in Central and Eastern Europe: A first exploration, International Economics and Economic Policy, 6, 179-206.

Sansó, A., Aragó, V., and Carrión, J. L. (2004) Testing for changes in the unconditional variance of financial time series, Revista de Economía Financiera, 4, 32-53. 
Solakoglu, M. N. (2010) Exchange rate exposure and real exports, Applied Economics Letters, 17, 457 - 462.

Solakoglu, M. N., Solakoglu, E. G. and Demirağ, T. (2008) Exchange rate volatility and exports: A firm-level analysis, Applied Economics, 40, 1466-4283.

Stock, J.H. and Watson, M.W. (2002) Has the business cycle changed and why?, NBER Macroeconomics Annual, 17, 159-218.

The Economist (2007) The Big Mac index. 1 February 2007.

Valentinyi-Endrész, M. (2004) Structural breaks and financial risk management, MNB Working Paper 11, Magyar Nemzeti Bank, Budapest. 
Table 1. Multiple Structural Breaks in Volatility: Nominal Exchange Rates Against Euro, G-7 Countries

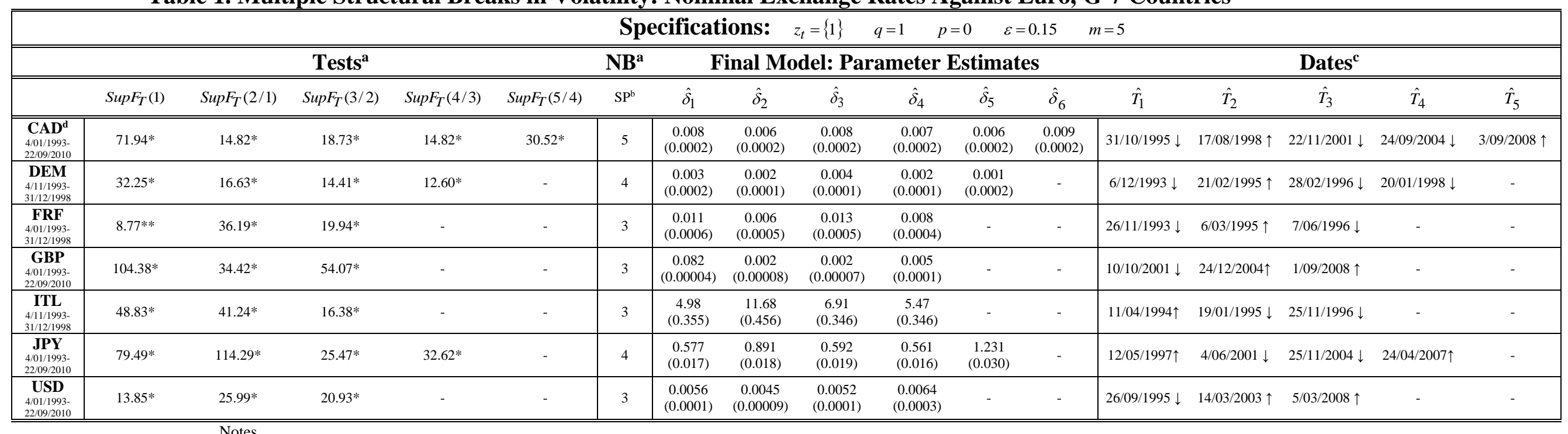

Notes.

a. $\operatorname{SupF}_{T}(1)$ is the sup F type test of no structural breaks versus the alternative hypothesis that there are $\mathrm{m}=1$ breaks. The $\operatorname{SupF}_{T}(\ell+1 / \ell)$ are the sup F type tests for $\ell$ versus $\ell+1$ breaks $*, * *, * * *$ indicate significance at $1 \%, 5 \%$ and $10 \%$, respectively. NB: number of breaks.

b. SP: sequential procedure by Bai and Perron $(1998,2003)$.

c. $\uparrow$ or $\downarrow$ denotes, respectively, the increase or reduction in volatility suggested by the coefficient estimates.

d. CAD: Canada, Dollar; DEM: Germany, Mark; FRF: France, Frank; GBP: United Kingdom, Pound; ITL: Italy, Lira; JPY: Japan, Yen; USD: United States, Dollar. 
Table 2. Multiple Structural Breaks in Volatility: Nominal Exchange Rates Against Euro, European Countries

\begin{tabular}{|c|c|c|c|c|c|c|c|c|c|c|c|c|c|c|c|c|c|}
\hline & \multirow{2}{*}{\multicolumn{5}{|c|}{ Tests $^{\mathbf{a}}$}} & \multicolumn{3}{|c|}{ Specifications: } & $z_{t}=\{1\}$ & $q=1$ & $p=0$ & $\varepsilon=0.15$ & $m=5$ & & & & \\
\hline & & & & & & \multirow{2}{*}{$\frac{\mathbf{N B}^{\mathbf{a}}}{\mathrm{SP}^{\mathrm{b}}}$} & \multicolumn{6}{|c|}{ Final Model: Parameter Estimates } & \multicolumn{5}{|c|}{ Dates $^{\mathrm{c}}$} \\
\hline & $\operatorname{SupF}_{T}(1)$ & $\operatorname{SupF}_{T}(2 / 1)$ & $\operatorname{SupF}_{T}(3 / 2)$ & $\operatorname{SupF}_{T}(4 / 3)$ & $\operatorname{SupF}_{T}(5 / 4)$ & & $\hat{\delta}_{1}$ & $\hat{\delta}_{2}$ & $\hat{\delta}_{3}$ & $\hat{\delta}_{4}$ & $\hat{\delta}_{5}$ & $\hat{\delta}_{6}$ & $\hat{T}_{1}$ & $\hat{T}_{2}$ & $\hat{T}_{3}$ & $\hat{T}_{4}$ & $\hat{T}_{5}$ \\
\hline $\begin{array}{r}\text { ATS }^{\mathbf{d}} \\
4 / 0 / 1 / 1993- \\
31 / 12 / 1998 \\
\end{array}$ & $333.21^{*}$ & $27.93 *$ & $11.41 * *$ & - & - & 3 & $\begin{array}{c}0.075 \\
(0.002)\end{array}$ & $\begin{array}{c}0.052 \\
(0.0017)\end{array}$ & $\begin{array}{c}0.021 \\
(0.0017)\end{array}$ & $\begin{array}{c}0.016 \\
(0.002)\end{array}$ & - & - & $30 / 11 / 1993 \downarrow$ & 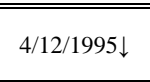 & $26 / 01 / 1998 \downarrow$ & - & - \\
\hline $\begin{array}{c}\text { BEF } \\
4 / 01 / 1993- \\
31 / 12 / 1998 \\
\end{array}$ & $34.51^{*}$ & $11.19 * *$ & - & - & - & 2 & $\begin{array}{c}0.081 \\
(0.003)\end{array}$ & $\begin{array}{c}0.059 \\
(0.004)\end{array}$ & $\begin{array}{c}0.042 \\
(0.005)\end{array}$ & - & - & - & $25 / 03 / 1996 \downarrow$ & $26 / 01 / 1998 \downarrow$ & - & - & - \\
\hline $\begin{array}{c}\text { CHF } \\
4 / 01 / 1993- \\
22 / 09 / 2010 \\
\end{array}$ & $262.75^{*}$ & $89.43 *$ & - & - & - & 2 & \begin{tabular}{|c|}
0.004 \\
$(0.00007)$ \\
\end{tabular} & $\begin{array}{c}0.002 \\
(0.00006) \\
\end{array}$ & $\begin{array}{c}0.005 \\
(0.0002) \\
\end{array}$ & - & - & - & $5 / 02 / 1999 \downarrow$ & $7 / 09 / 2007 \uparrow$ & - & - & - \\
\hline $\begin{array}{c}\text { CYP } \\
14 / 11 / 1996- \\
805 / 2007\end{array}$ & $302.69^{*}$ & $497.28^{*}$ & - & - & - & 2 & $\begin{array}{c}0.001 \\
(0.0001)\end{array}$ & $\begin{array}{c}0.003 \\
(0.00006)\end{array}$ & $\begin{array}{c}0.0012 \\
(0.00009)\end{array}$ & - & - & - & $25 / 11 / 1998 \uparrow$ & 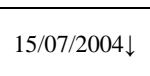 & - & - & - \\
\hline $\begin{array}{c}\text { DKK } \\
4 / 21 / 1993- \\
22 / 19010\end{array}$ & $432 *$ & $251.15^{*}$ & $36.30^{*}$ & $25.73 *$ & $25.73^{*}$ & 5 & $\begin{array}{c}0.013 \\
(0.0003)\end{array}$ & $\begin{array}{c}0.009 \\
(0.0004)\end{array}$ & $\begin{array}{c}0.006 \\
(0.0004)\end{array}$ & $\begin{array}{c}0.003 \\
(0.0001)\end{array}$ & $\begin{array}{c}0.001 \\
(0.0009)\end{array}$ & $\begin{array}{c}0.002 \\
(0.0005)\end{array}$ & $5 / 06 / 1996 \downarrow$ & 17/01/1999」 & $17 / 04 / 2001 \downarrow$ & $24 / 07 / 2003 \downarrow$ & $1 / 05 / 2007 \uparrow$ \\
\hline $\begin{array}{c}\text { ESP } \\
\text { E/101/1993- } \\
3 / 121 / 1998\end{array}$ & $39.62 *$ & $26.09 *$ & $17.84 *$ & $17.84 *$ & - & 4 & $\begin{array}{c}0.511 \\
(0.026)\end{array}$ & $\begin{array}{c}0.372 \\
(0.022)\end{array}$ & $\begin{array}{c}0.263 \\
(0.022)\end{array}$ & $\begin{array}{c}0.608 \\
(0.027)\end{array}$ & $\begin{array}{c}0.433 \\
(0.029)\end{array}$ & - & $27 / 01 / 1994 \downarrow$ & $24 / 07 / 1995 \downarrow$ & $23 / 01 / 1997 \uparrow$ & $4 / 02 / 1998 \downarrow$ & - \\
\hline $\begin{array}{c}\text { IEP } \\
4 / 01 / 1993- \\
31 / 12 / 1998 \\
\end{array}$ & $119.09^{*}$ & $14.10^{*}$ & - & - & - & 2 & $\begin{array}{c}0.001 \\
(0.0001)\end{array}$ & $\begin{array}{c}0.002 \\
(0.00008)\end{array}$ & $\begin{array}{c}0.001 \\
(0.0001)\end{array}$ & - & - & - & $10 / 02 / 1995 \uparrow$ & $23 / 12 / 1997 \downarrow$ & - & - & - \\
\hline $\begin{array}{c}\text { LUF } \\
14 / 11 / 1996- \\
8 / 05 / 2007\end{array}$ & $12.05^{*}$ & $26.97 *$ & - & - & - & 2 & $\begin{array}{l}0.0069 \\
(0.005)\end{array}$ & $\begin{array}{c}0.035 \\
(0.007)\end{array}$ & $\begin{array}{l}0.1029 \\
(0.010)\end{array}$ & - & - & - & $4 / 01 / 1998 \downarrow$ & $31 / 08 / 1998 \uparrow$ & - & - & - \\
\hline $\begin{array}{c}\text { MTL } \\
\text { 21/1088/1/298- } \\
800 / 2007\end{array}$ & $99.73^{*}$ & $54.51^{*}$ & $34.93 *$ & - & - & 3 & $\begin{array}{c}0.002 \\
(0.00007)\end{array}$ & $\begin{array}{c}0.0016 \\
(0.00007)\end{array}$ & $\begin{array}{c}0.00011 \\
(0.00006)\end{array}$ & $\begin{array}{c}0.0008 \\
(0.00005)\end{array}$ & - & - & $28 / 04 / 2000 \downarrow$ & $7 / 12 / 2001 \downarrow$ & $23 / 03 / 2004 \downarrow$ & - & - \\
\hline $\begin{array}{c}\text { NOK } \\
401 / 1993-3 \\
22 / 09 / 2010\end{array}$ & $277.37^{*}$ & $27.28 *$ & $22.14 *$ & $23.71 *$ & $25.02 *$ & 5 & \begin{tabular}{|c|}
0.013 \\
$(0.0006)$ \\
\end{tabular} & $\begin{array}{c}0.030 \\
(0.0009) \\
\end{array}$ & $\begin{array}{c}0.020 \\
(0.0006)\end{array}$ & $\begin{array}{c}0.028 \\
(0.0001)\end{array}$ & $\begin{array}{c}0.021 \\
(0.0008) \\
\end{array}$ & $\begin{array}{c}0.043 \\
\quad(0.001) \\
\end{array}$ & $9 / 01 / 1997 \uparrow$ & $29 / 03 / 1999 \downarrow$ & $9 / 01 / 2003 \downarrow$ & $3 / 03 / 2005 \downarrow$ & $12 / 09 / 2008 \uparrow$ \\
\hline $\begin{array}{c}\text { PTE } \\
4 / 01 / 119933 \\
31 / 121 / 1998\end{array}$ & $97.50 *$ & $29.28 *$ & - & - & - & 2 & $\begin{array}{c}0.560 \\
(0.030)\end{array}$ & $\begin{array}{c}0.311 \\
(0.020)\end{array}$ & $\begin{array}{c}0.639 \\
(0.017)\end{array}$ & - & - & - & 27/12/1993」 & $6 / 02 / 1996 \uparrow$ & - & - & - \\
\hline $\begin{array}{c}\text { SEK } \\
4 / 01 / 1993- \\
22 / 09 / 2010 \\
\end{array}$ & $271.16^{*}$ & $36.83^{*}$ & $10.59^{* * *}$ & $10.59^{* * *}$ & - & 4 & $\begin{array}{c}0.038 \\
(0.0009) \\
\end{array}$ & $\begin{array}{c}0.027 \\
(0.001) \\
\end{array}$ & $\begin{array}{c}0.031 \\
(0.0008) \\
\end{array}$ & $\begin{array}{c}0.019 \\
(0.0007) \\
\end{array}$ & $\begin{array}{c}0.054 \\
(0.001) \\
\end{array}$ & - & $13 / 12 / 1995 \downarrow$ & $24 / 08 / 1998 \uparrow$ & $23 / 10 / 2002 \downarrow$ & $29 / 09 / 2008 \uparrow$ & - \\
\hline $\begin{array}{c}\text { TRY } \\
4 / 01 / 1993- \\
22 / 09 / 2010 \\
\end{array}$ & $26.47^{*}$ & $207.06^{*}$ & $205.40^{*}$ & $205.40^{*}$ & $65.02 *$ & 5 & $\begin{array}{c}0.271 \\
(0.221)\end{array}$ & $\begin{array}{c}0.269 \\
(0.282)\end{array}$ & $\begin{array}{c}0.265 \\
(0.257)\end{array}$ & $\begin{array}{c}1.679 \\
(0.0006) \\
\end{array}$ & $\begin{array}{c}1.271 \\
(0.0003) \\
\end{array}$ & $\begin{array}{c}0.824 \\
\quad(0.0007) \\
\end{array}$ & $1 / 07 / 1996 \downarrow$ & $25 / 08 / 1998 \downarrow$ & $3 / 04 / 2001 \uparrow$ & $29 / 05 / 2003 \downarrow$ & $21 / 01 / 2009 \downarrow$ \\
\hline
\end{tabular}

Notes.

a. $\operatorname{SupF}_{T}(1)$ is the sup F type test of no structural breaks versus the alternative hypothesis that there are $\mathrm{m}=1$ breaks. The $\operatorname{SupF}_{T}(\ell+1 / \ell)$ are the sup F type tests for $\ell$ versus $\ell+1$ breaks. $*, * *, * * *$ indicate significance at $1 \%, 5 \%$ and $10 \%$, respectively. NB: number of breaks.

b. SP: sequential procedure by Bai and Perron $(1998,2003)$.

d. ATS: Austria, Schilling: BEF: Belgium, Franc; CHF. Switzerland, Franc; CYP. Cyprus, Pounds; DKK: Denmark, Kroner, ESP: Spain, Peseta; IEP: Ireland, Pound; LUF: Luxembourg, Franc;

MTL: Malta, Lira; NOK: Norway, Kroner; PTE: Portugal, Escudo; SEK: Sweden, Kronor; TRY: Turkey, New Lira 
Table 3. Multiple Structural Breaks in Volatility: Nominal Exchange Rates Against Euro, Transition Economies

\begin{tabular}{|c|c|c|c|c|c|c|c|c|c|c|c|c|c|c|c|c|c|}
\hline & \multirow[b]{3}{*}{$\operatorname{SupF}_{T}(1)$} & \multirow[b]{3}{*}{$\operatorname{SupF}_{T}(2 / 1)$} & \multirow{3}{*}{$\begin{array}{l}\text { Tests }^{\mathbf{a}} \\
\operatorname{SupF}_{T}(3 / 2)\end{array}$} & \multirow[b]{3}{*}{$\operatorname{SupF}_{T}(4 / 3)$} & \multicolumn{4}{|c|}{ Specifications: } & $z_{t}=\{1\}$ & $q=1$ & \multicolumn{2}{|c|}{$p=0 \quad \varepsilon=0.15$} & \multicolumn{2}{|l|}{$m=5$} & \multirow{2}{*}{ Dates $^{\mathbf{c}}$} & \multirow[b]{3}{*}{$\hat{T}_{4}$} & \multirow[b]{3}{*}{$\hat{T}_{5}$} \\
\hline & & & & & & $\mathbf{N B}^{\mathbf{a}}$ & & inal $M$ & del: Pa & ameter & Estimat & tes & & & & & \\
\hline & & & & & $\operatorname{SupF}_{T}(5 / 4)$ & $\mathrm{SP}^{\mathrm{b}}$ & 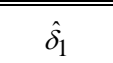 & 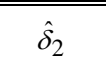 & 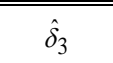 & 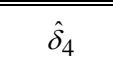 & 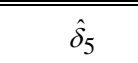 & $\bar{\delta}_{6}$ & $\overline{\overline{T_{1}}}$ & 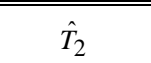 & $\overline{\overline{T_{3}}}$ & & \\
\hline 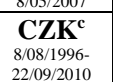 & $164.55^{*}$ & $49.77^{*}$ & $50.22^{*}$ & - & - & 3 & $\begin{array}{c}0.161 \\
(0.004)\end{array}$ & $\begin{array}{c}0.096 \\
(0.004)\end{array}$ & $\begin{array}{c}0.074 \\
(0.003)\end{array}$ & $\begin{array}{c}0.111 \\
(0.004)\end{array}$ & - & - & $14 / 11 / 2000 \downarrow$ & 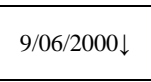 & $1 / 10 / 2008 \uparrow$ & - & - \\
\hline $\begin{array}{c}\text { HUF } \\
16 / 1 / 1 / 1995- \\
22 / 09 / 2010\end{array}$ & $36.32 *$ & $12.38^{*}$ & $12.38^{*}$ & - & - & 3 & $\begin{array}{c}0.650 \\
(0.038)\end{array}$ & $\begin{array}{c}0.794 \\
(0.038)\end{array}$ & $\begin{array}{c}1.084 \\
(0.047)\end{array}$ & $\begin{array}{c}1.963 \\
(0.054)\end{array}$ & - & - & $12 / 03 / 1998 \downarrow$ & 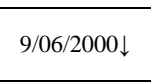 & $22 / 08 / 2008 \uparrow$ & - & - \\
\hline $\begin{array}{l}\text { PLN } \\
16 / 1 / 1 / 1995- \\
2201 / 2010\end{array}$ & $170.24 *$ & $53.26^{*}$ & $52.10^{*}$ & $23.21 *$ & - & 4 & $\begin{array}{c}0.01 \\
(0.0008)\end{array}$ & $\begin{array}{c}0.023 \\
(0.0005)\end{array}$ & $\begin{array}{c}0.019 \\
(0.0006)\end{array}$ & $\begin{array}{c}0.010 \\
(0.0008)\end{array}$ & $\begin{array}{c}0.029 \\
(0.0008)\end{array}$ & - & $25 / 09 / 1997 \downarrow$ & $21 / 12 / 2001 \downarrow$ & $7 / 06 / 2005 \downarrow$ & $26 / 08 / 2008 \uparrow$ & - \\
\hline $\begin{array}{c}\mathbf{R O N} \\
\begin{array}{c}14 / 1 / 1 / 1996- \\
22109 / 2010\end{array} \\
\end{array}$ & $12.29 *$ & $218.49^{*}$ & $196.31^{*}$ & $42.57^{*}$ & $42.52 *$ & 5 & $\begin{array}{c}0.018 \\
(0.0001) \\
\end{array}$ & $\begin{array}{c}0.020 \\
(0.0001)\end{array}$ & $\begin{array}{c}0.023 \\
(0.0005) \\
\end{array}$ & $\begin{array}{c}0.010 \\
(0.0007) \\
\end{array}$ & $\begin{array}{c}0.019 \\
(0.0008) \\
\end{array}$ & $\begin{array}{c}0.010 \\
(0.0008) \\
\end{array}$ & $13 / 12 / 1999 \downarrow$ & 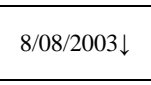 & $28 / 02 / 2005 \downarrow$ & $24 / 07 / 2007 \uparrow$ & $14 / 01 / 2009 \downarrow$ \\
\hline $\begin{array}{c}\text { RUB } \\
16 / 1 / 1 / 1995- \\
22 / 09 / 2010\end{array}$ & $555.68^{*}$ & $129.03^{*}$ & $218.03 *$ & $44.26^{*}$ & - & 4 & $\begin{array}{c}0.034 \\
(0.011) \\
\end{array}$ & $\begin{array}{c}0.504 \\
(00013)\end{array}$ & $\begin{array}{c}0.165 \\
(0.004) \\
\end{array}$ & $\begin{array}{c}0.085 \\
(0.004) \\
\end{array}$ & $\begin{array}{c}0.201 \\
(0.006) \\
\end{array}$ & - & $23 / 07 / 1998 \downarrow$ & 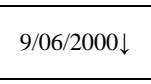 & $8 / 03 / 2005 \downarrow$ & $4 / 12 / 2008 \uparrow$ & - \\
\hline \begin{tabular}{|c|} 
SIT \\
$2 / 1 / 99 / 2003-$ \\
$29 / 12 / 2006$ \\
\end{tabular} & $27.06^{* *}$ & - & - & - & - & 1 & $\begin{array}{l}0.2331 \\
(0.013) \\
\end{array}$ & $\begin{array}{c}0.135 \\
(0.020) \\
\end{array}$ & - & - & & & $29 / 12 / 2005 \downarrow$ & - & - & - & - \\
\hline $\begin{array}{c}\text { SKK } \\
14 / 1 / 1 / 1996- \\
31 / 1 / 2008\end{array}$ & $144.44 *$ & $45.76^{*}$ & $13.92^{*}$ & $12.50^{* *}$ & $12.50^{* * *}$ & 5 & $\begin{array}{c}0.136 \\
(0.007)\end{array}$ & $\begin{array}{c}0.234 \\
(0.007)\end{array}$ & $\begin{array}{c}0.106 \\
(0.007)\end{array}$ & $\begin{array}{c}0.074 \\
(0.007)\end{array}$ & $\begin{array}{c}0.089 \\
(0.003)\end{array}$ & $\begin{array}{c}0.062 \\
(0.007)\end{array}$ & $28 / 09 / 1998 \uparrow$ & $29 / 12 / 2000 \downarrow$ & $30 / 12 / 2002 \downarrow$ & $2 / 02 / 2005 \uparrow$ & $4 / 04 / 2007 \downarrow$ \\
\hline
\end{tabular}

a. $S u p F_{T}(1)$ is the sup $\mathrm{F}$ type test of no structural breaks versus the alternative hypothesis that there are $\mathrm{m}=1$ breaks. The $\operatorname{Sup} F_{T}(\ell+1 / \ell)$ are the sup $\mathrm{F}$ type tests for $\ell$ versus $\ell+1$ breaks.

$* * * * * *$ indicate significance at $1 \%, 5 \%$ and $10 \%$, respectively NB: number of breaks.

b. SP: sequential procedure by Bai and Perron $(1998,2003)$.

c. $\uparrow$ or $\downarrow$ denotes, respectively, the increase or reduction in volatility suggested by the coefficient estimates.

d.. BGN: Bulgaria, Leva; CZK: Czech Republic, Koruny; HUF: Hungary, Forint; PLN: Poland, Zlotys; RON: Romania, New Leu; RUB: Russia, Rubbles; SIT: Slovenia, Tolars; SKK: Slovakia,

Koruny; 
Table 4. Multiple Structural Breaks in Volatility: Nominal Exchange Rates Against Euro, Other Countries

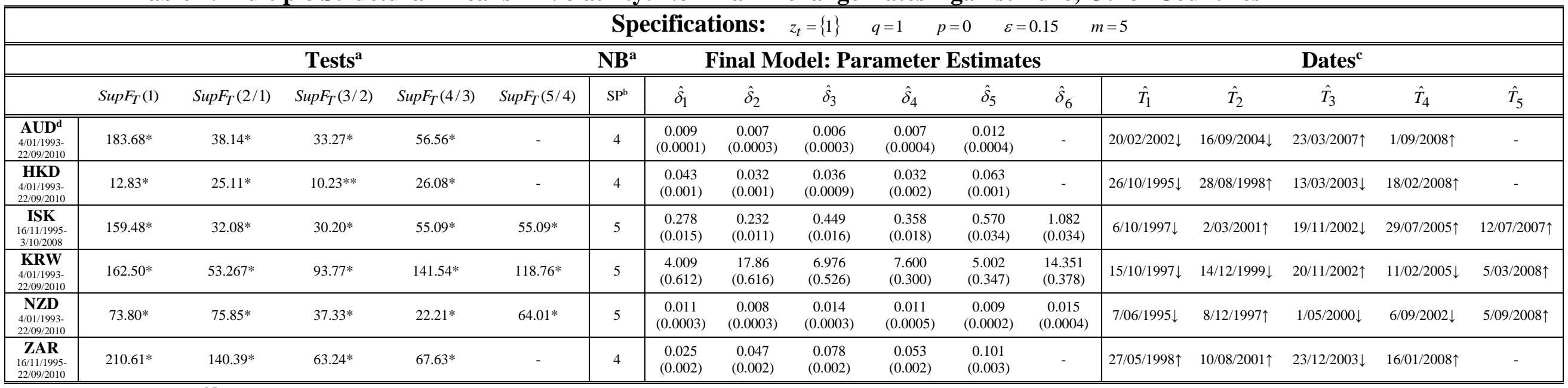

a. $\operatorname{SupF}_{T}(1)$ is the sup F type test of no structural breaks versus the alternative hypothesis that there are $\mathrm{m}=1$ breaks. The $\operatorname{SupF}_{T}(\ell+1 / \ell)$ are the sup F type tests for $\ell$ versus $\ell+1$ breaks.

$*, * *, * *$ indicate significance at $1 \%, 5 \%$ and $10 \%$, respectively. NB: number of breaks.

b. SP: sequential procedure by Bai and Perron $(1998,2003)$.

c. $\uparrow$ or $\downarrow$ denotes, respectively, the increase or reduction in volatility suggested by the coefficient estimates

d.. AUD: Australia, Dollar; HKD: Hong Kong, Dollar; ISK: Iceland, Kronur; KRW: Korea, Won; NZD: New Zealand, Dollar; ZAR: South Africa, Rand 

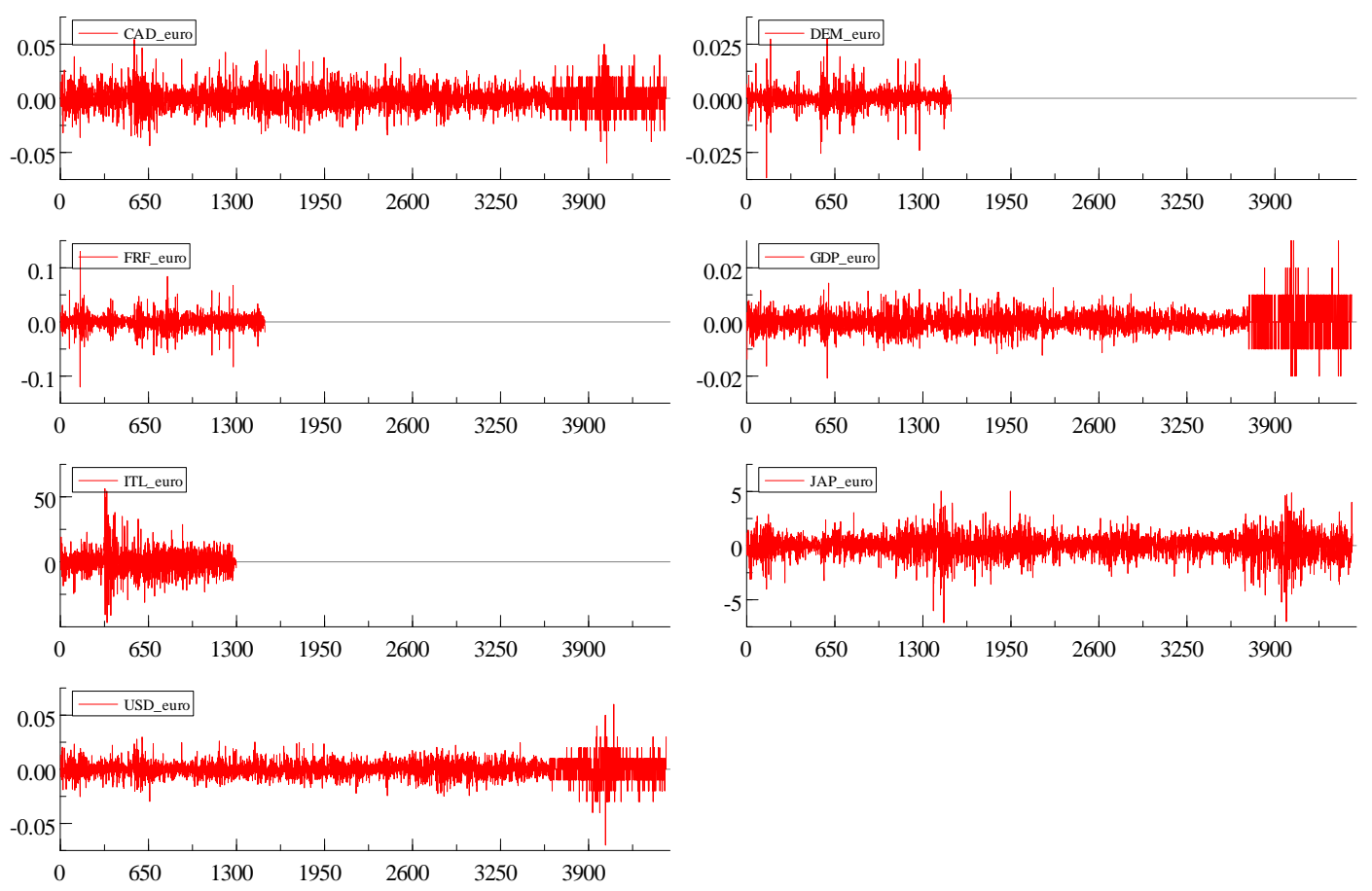

Figure 1 (a). Daily rate of change of nominal exchange rates against euro, G-7 countries. 

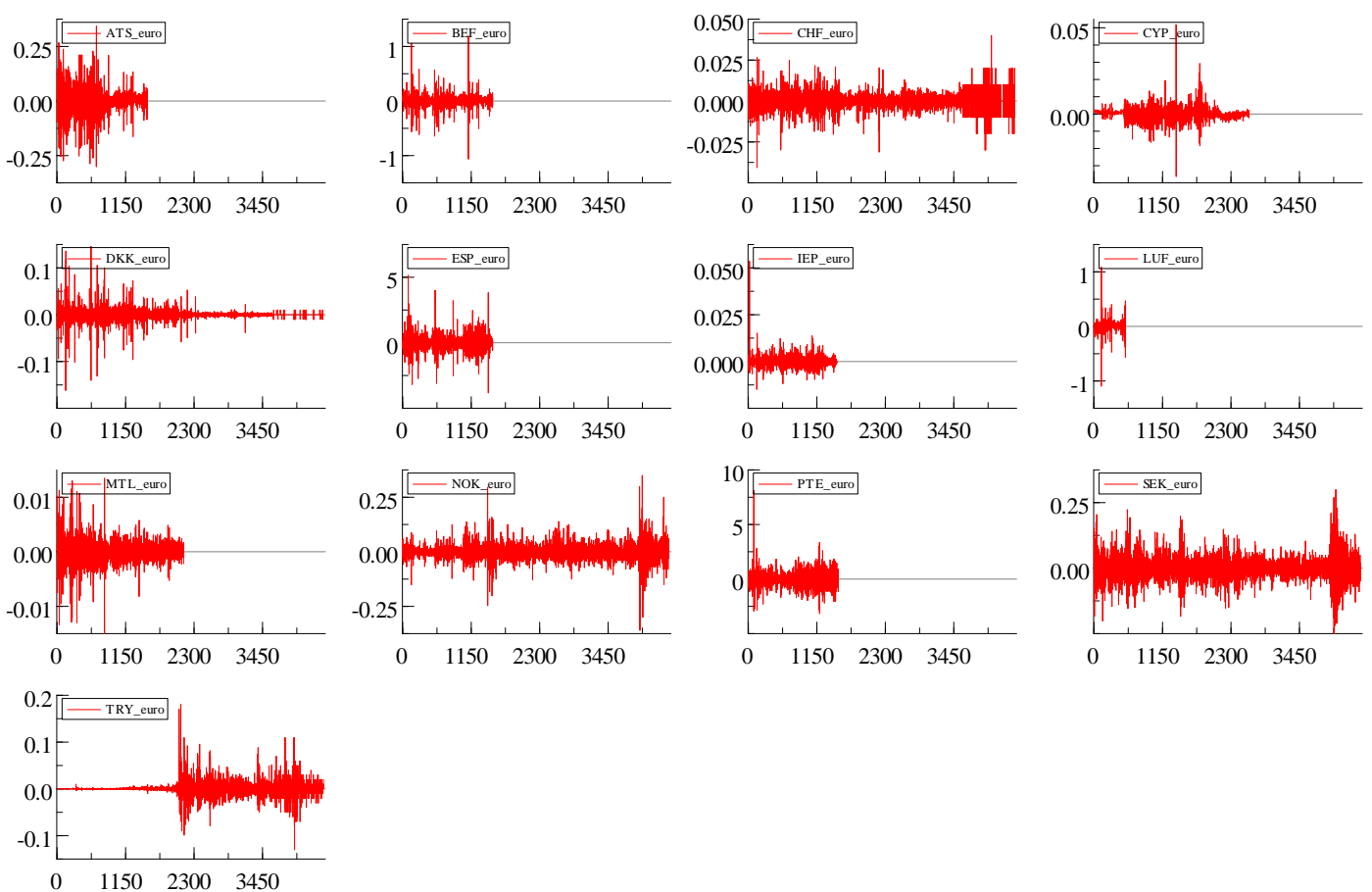

Figure 1 (b). Daily rate of change of nominal exchange rates against euro, European countries. 

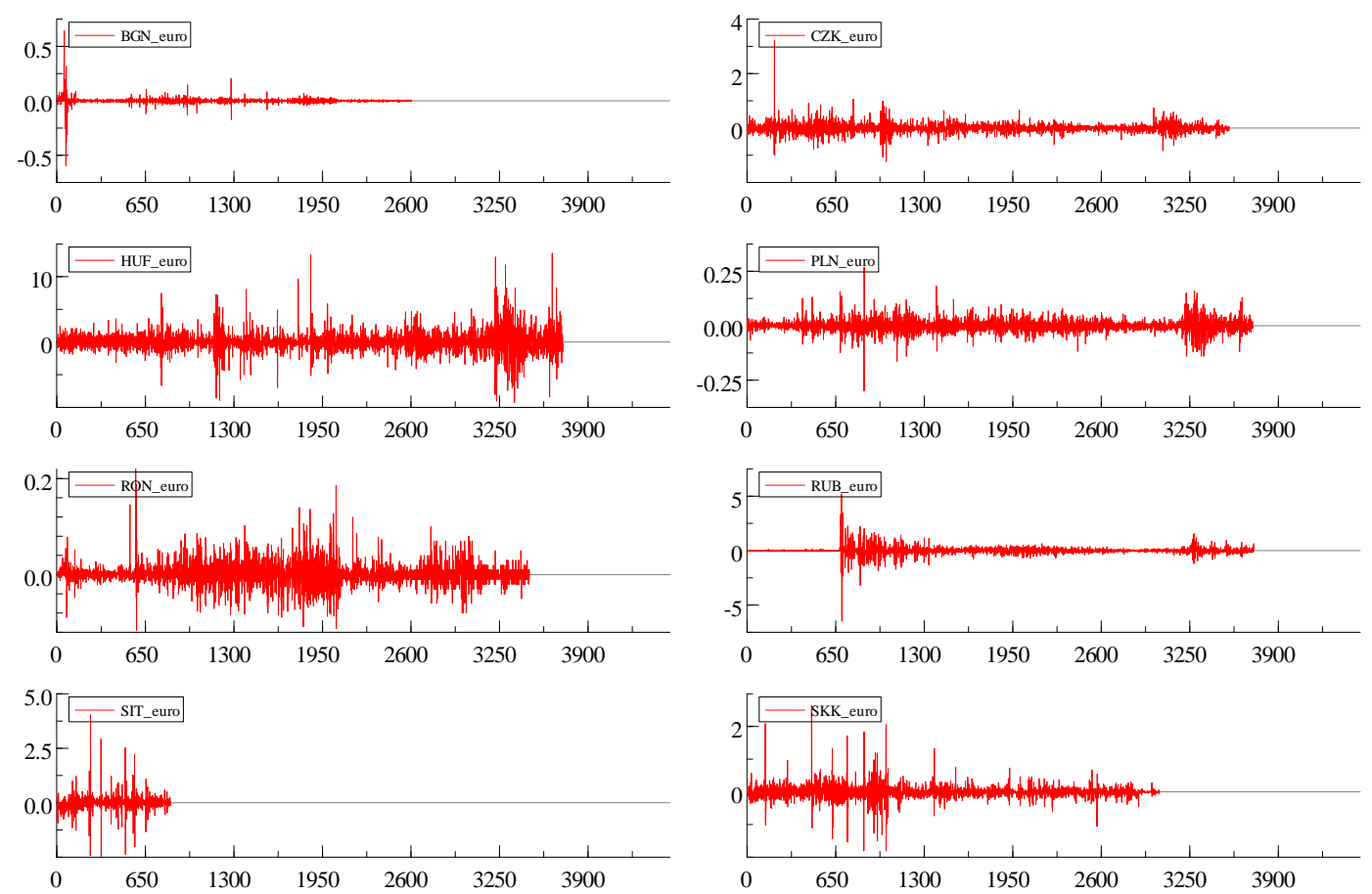

Figure 1 (c). Daily rate of change of nominal exchange rates against euro, Transition Economies countries. 

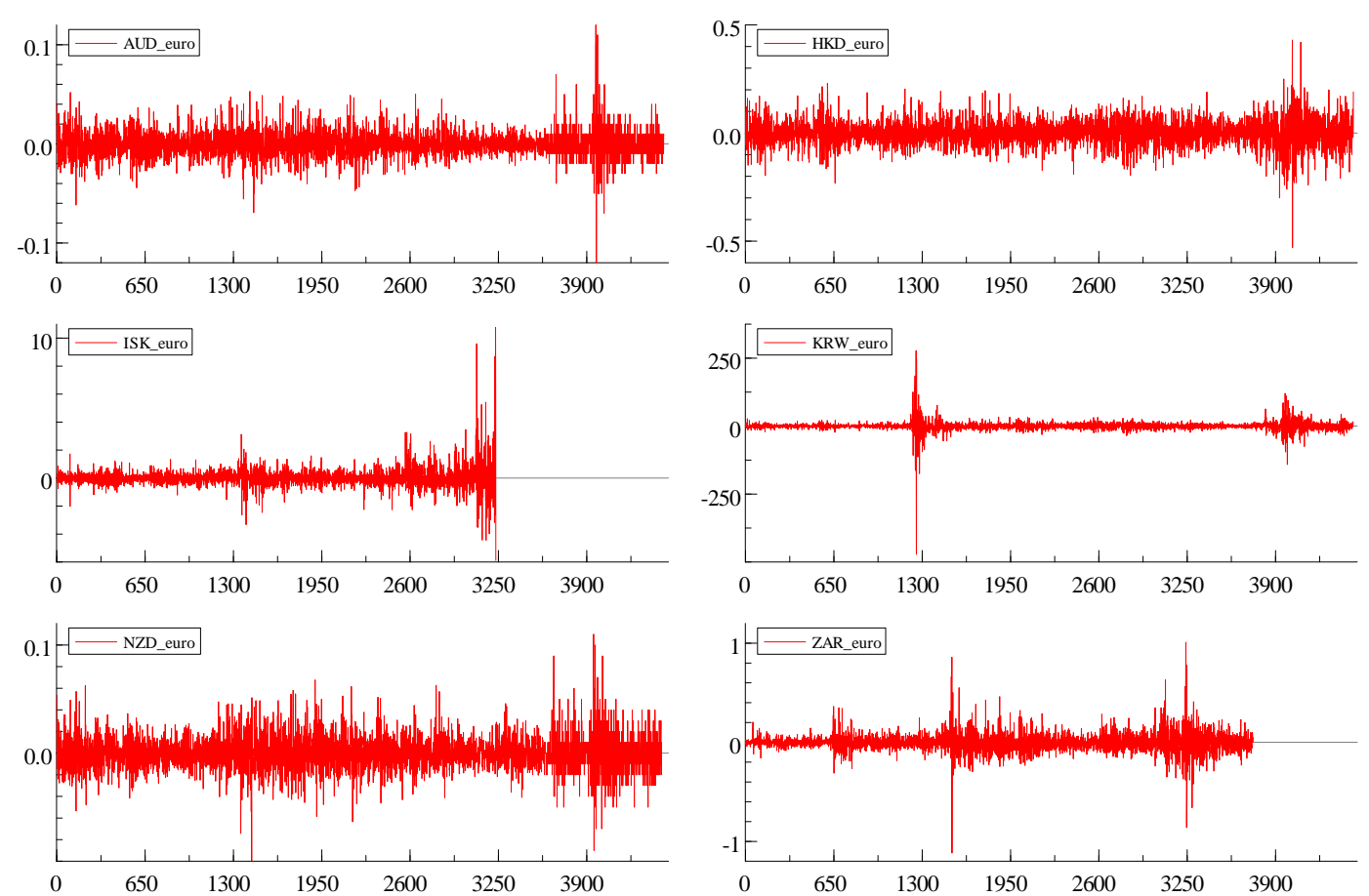

Figure 1 (d). Daily rate of change of nominal exchange rates against euro, other countries. 


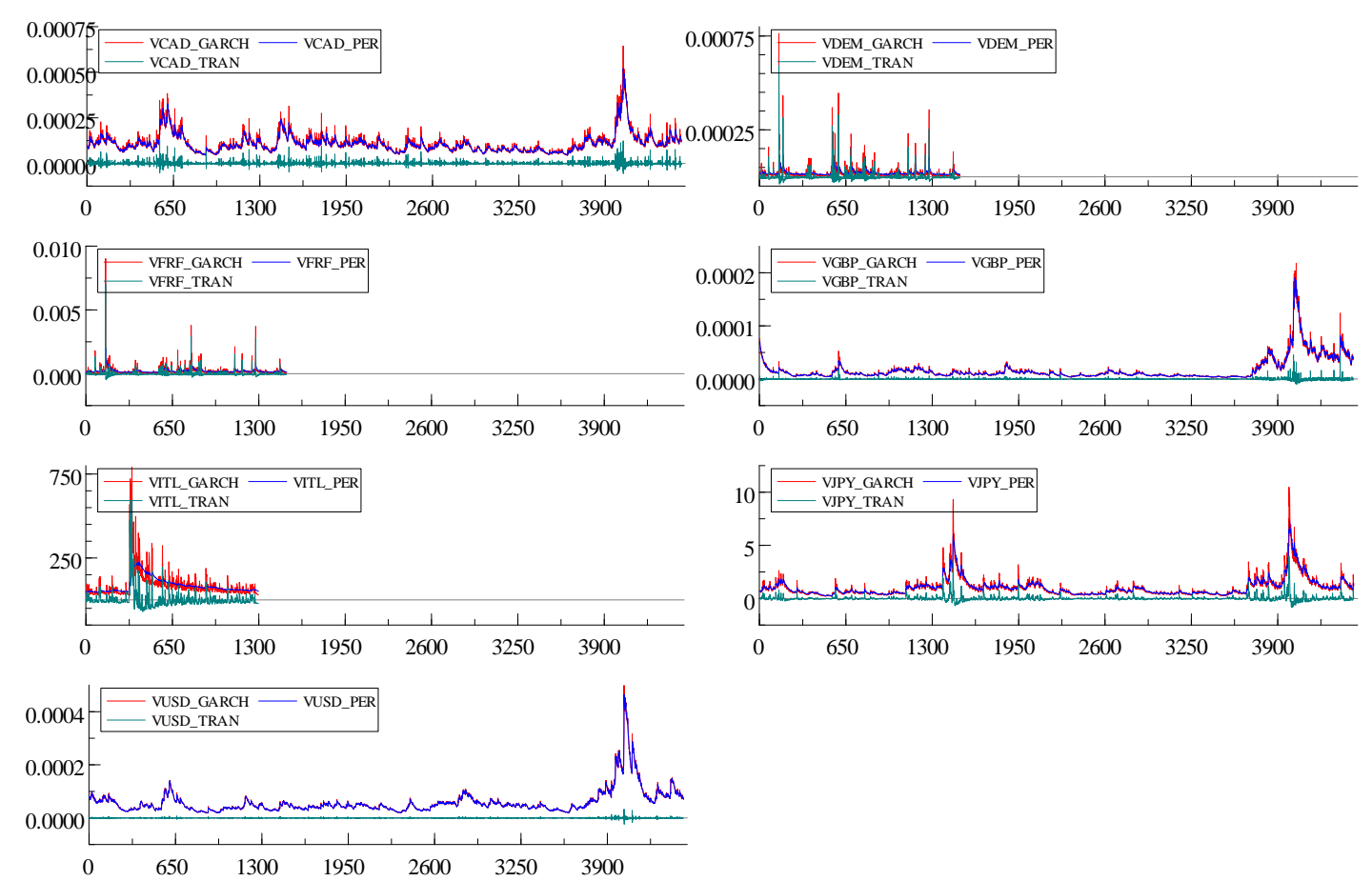

Figure 2(a). Total, permanent and transitory variance in nominal exchange rates against euro, G-7 countries. 

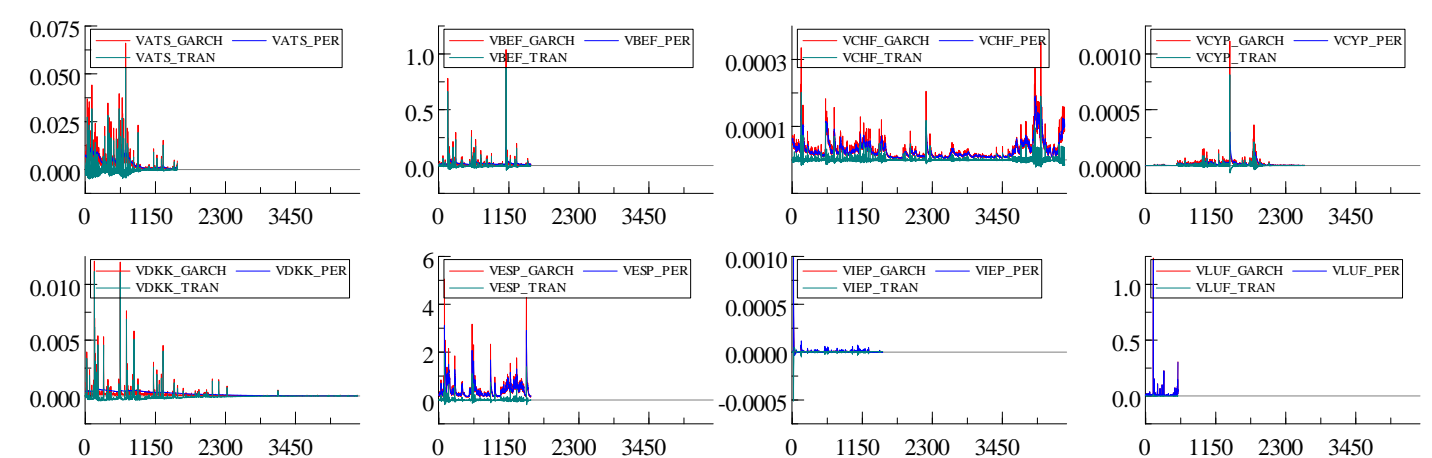

$\begin{array}{llll}0 & 1150 & 2300 & 3450\end{array}$

$\begin{array}{llll}0 & 1150 & 2300 & 3450\end{array}$
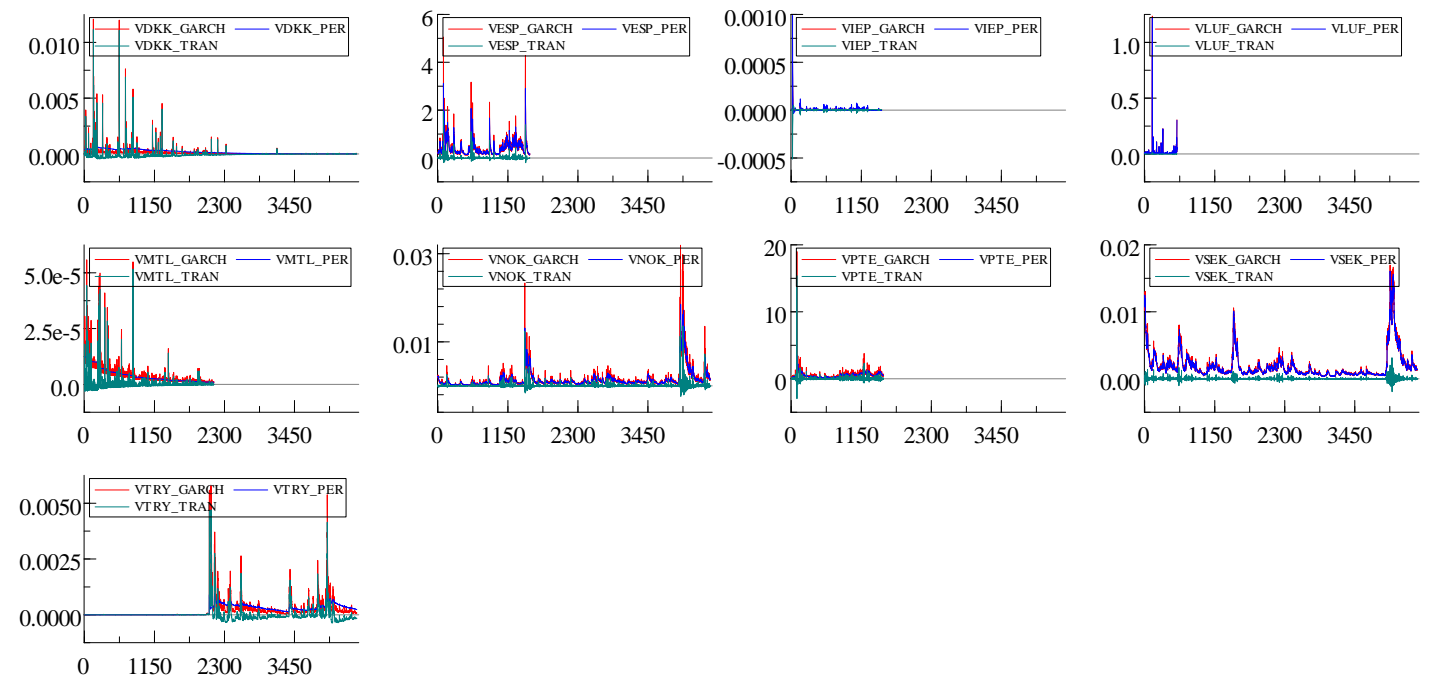

Figure 2(b). Total, permanent and transitory variance in nominal exchange rates against euro, European countries. 

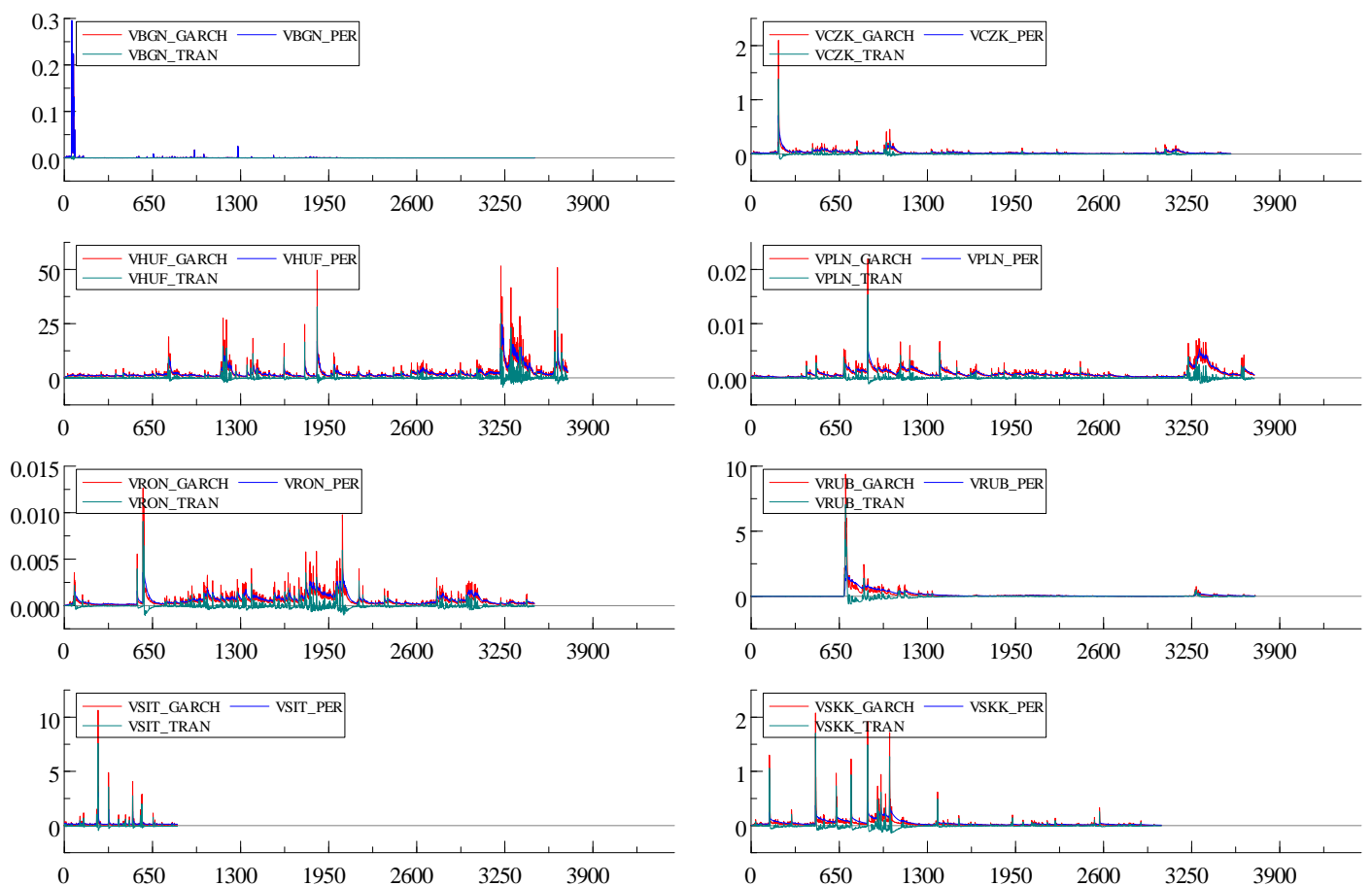

Figure 2(c). Total, permanent and transitory variance in nominal exchange rates against euro, Transition Economies countries. 

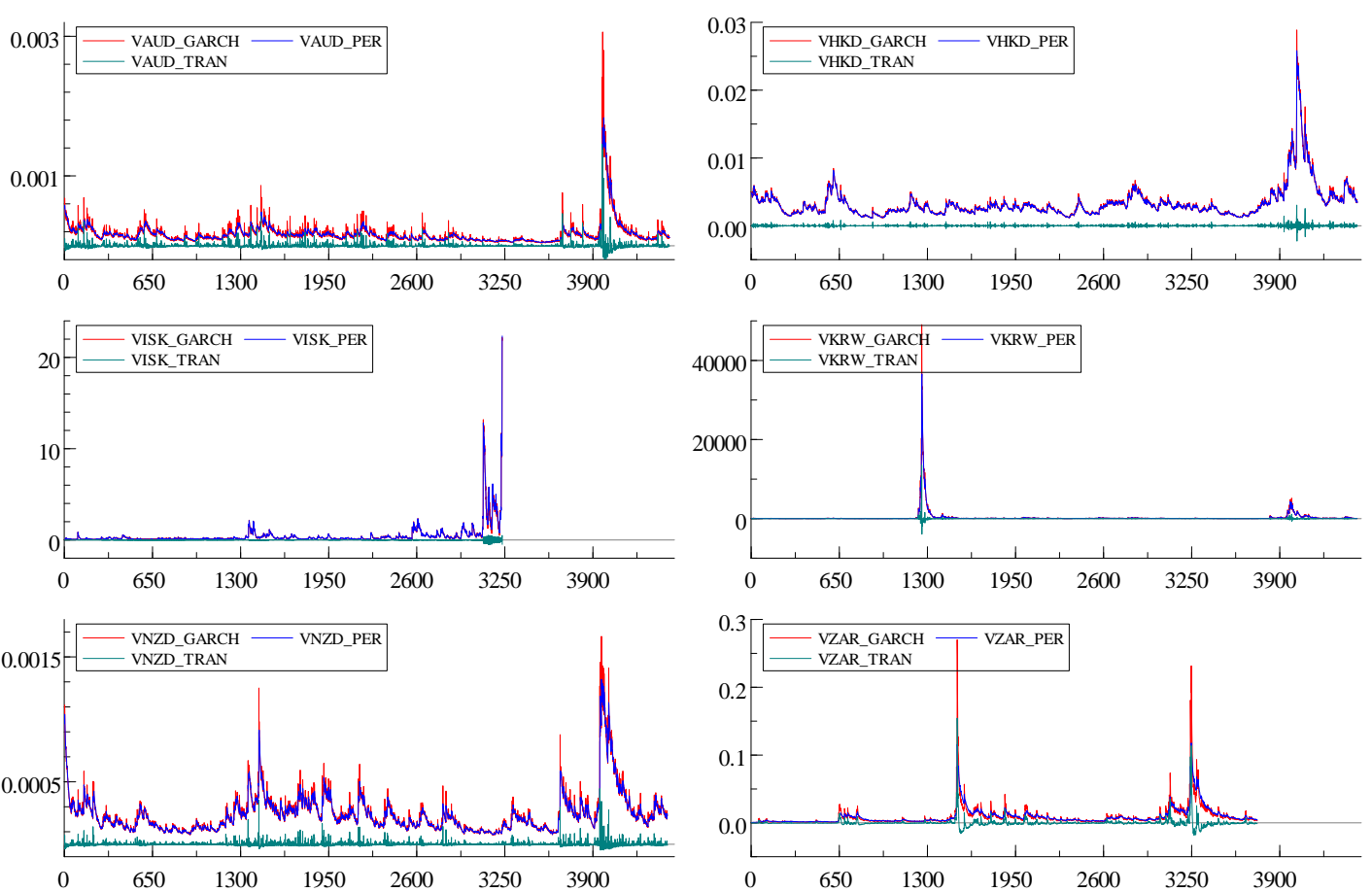

Figure 2(d). Total, permanent and transitory variance in nominal exchange rates against euro, other countries. 